\title{
ZMIANY STANU CYWILNEGO WE WSPÓŁCZESNEJ EUROPIE - KIERUNEK PRZEMIAN ORAZ ICH DETERMINANTY
}

\section{CHANGES OF MARITAL STATUS IN MODERN EUROPE - THEIR DIRECTIONS AND DETERMINANTS}

\author{
Adrianna Szwarc ${ }^{1(\mathrm{~A}, \mathrm{~B}, \mathrm{C}, \mathrm{D}, \mathrm{E}, \mathrm{F})}$
}

${ }^{1}$ Instytut Psychologii, Uniwersytet Jagielloński w Krakowie

\begin{abstract}
Szwarc A. (2017), Zmiany stanu cywilnego we współczesnej Europie - kierunek przemian oraz ich determinanty. Rozprawy Społeczne, 11(3), s. 14-21.
\end{abstract}
Wkład autorów:

A. Zaplanowanie badań

B. Zebranie danych

C. Dane - analiza i statystyki

D. Interpretacja danych

E. Przygotowanie artykułu

F. Wyszukiwanie i analiza

literatury

G. Zebranie funduszy

Tabele: 0

Ryciny: 0

Literatura: 64

Otrzymano: 03.02.2017

Zaakceptowano: 15.05.2017

\begin{abstract}
Streszczenie
Głównym celem niniejszego artykułu jest określenie najważniejszych czynników przyczyniajacych się na przestrzeni lat do podejmowania decyzji o małżeństwie lub rozwodzie, z uwzględnieniem zjawisk takich jak małżeństwa powtórne, separacja, kohabitacja i życie w pojedynkę. Na przestrzeni lat można bowiem zaobserwować spadek ilości zawieranych małżeństw i wzrost ilości rozwodów. Mimo iż małżeństwo uznawane jest za jedną z ważniejszych wartości w życiu i ciągle jest jednym z najpowszechniejszych wyborów to coraz częściej wybierane jest również życie w związku nieformalnym lub w pojedynkę. Taki stan rzeczy może być determinowany rozmaitymi czynnikami społecznymi, demograficznymi oraz instytucjonalnymi zapoczątkowanymi w Europie w latach 50 XX wieku; nie tylko takimi jak wspólne zamieszkiwanie przed ślubem czy społeczna akceptacja zjawiska rozwodu i małżeństw powtórnych, ale również większa niezależność kobiet lub też posiadanie w życiu ważniejszych celów niż wstąpienie w związek małżeński. Zaistniałe zmiany mogą prowadzić do wyboru form życia najbardziej odpowiadającym poszczególnym jednostkom, niezależnie od przyjętych norm społecznych.
\end{abstract}

Słowa kluczowe: małżeństwa, rozwody, małżeństwa powtórne, kohabitacja, single

\section{Summary}

The main aim of the following paper is to determine the most significant factors that have contributed to marriages and divorces over the years, including such phenomena as re-marriages, separations, cohabitations or single living. Over the years, a decrease in the number of marriages and growth in the number of divorces can be observed. Although marriage is reported to be one of the most important values in life and is still the most popular choice, living in a non-marital relationship or living alone has notably increased recently. It can be determined by a variety of social, demographical or institutional factors that originated in Europe in the 50s of the 20th century, not only such as living together before getting married, social acceptance of divorce and re-marriages but also a greater independence of women or having more important goals in life than getting married in the future. These changes may lead to selecting these forms of life that suit particular individuals most, regardless of the established social norms.

Keywords: marriages, divorces, re-marriages, cohabitation, being single

\section{Wstęp}

W ostatnim dziesięcioleciu obserwuje się zapoczątkowaną na przełomie lat 60 i $70 \mathrm{XX}$ wieku tendencję, przejawiającą się w spadku ilości zawieranych małżeństw i wzroście liczby rozwodów; zarówno w Polsce jak i w pozostałych europejskich krajach (Kwak 2005; Żurek 2010). Mimo tego, iż dla zdecydowanej większości ludzi szczęście rodzinne jest jedną z naczelnych wartości i mimo tego, że małżeństwo nadal uważane jest za najbardziej długotrwały i satysfakcjonujący rodzaj związku (Bakie- ra 2008; Poleszczuk 2002), to zauważa się, że rośnie społeczna akceptacja dla zjawiska rozwodu, zawierania małżeństw powtórnych, życia w związkach nieformalnych lub w pojedynkę (nawet w przypadku kobiet), pozamałżeńskich kontaktów seksualnych, a także dla dobrowolnie podjętych decyzji o samotnym macierzyństwie lub bezdzietności (Bakiera 2006; Łukasiewicz 2011; Kocik 2002; Slany, Kluzowa 2005; Slany 2008). Proces ten może być wynikiem zmiany uwarunkowań społecznych, ekonomicznych i politycznych, które zostały zapoczątkowane w latach 50 w Skandynawii i w latach 60 w Europie

Adres korespondencyjny: Adrianna Szwarc, Uniwersytet Jagielloński w Krakowie, Instytut Psychologii, Zakład Psychologii Eksperymentalnej, ul. Ingardena 6, 30-060 Kraków, e-mail: adrianna.szwarc@gmail.com, tel.: 126632413

Copyright by: Państwowa Szkoła Wyższa im. Papieża Jana Pawła II w Białej Podlaskiej, Adrianna Szwarc

Czasopismo Open Access, wszystkie artykuły udostępniane są na mocy licencji Creative Commons Uznanie autorstwa-użycie niekomercyjne-na tych samych warunkach 4.0 Międzynarodowe (CC BY-NC-SA 4.0, http://creativecommons.org/licenses/by-nc-sa/4.0/). 
Zachodniej, a następnie w latach 70 na południu Europy i w końcu, w latach 90 także w Polsce. (Kotowska 1999; Giza-Poleszczuk 2007). Powoduje to, że zwłaszcza w krajach bogatych coraz mniej powszechne stają się rodziny wielodzietne, a bardziej popularne rodziny małe. Maleje ilość rodzonych dzieci, a część małżeństw (nazywanych inaczej Double Income No Kids Yet; DINKY) całkowicie rezygnuje z posiadania potomstwa chociażby dlatego, że młoda para chce w większym stopniu skupić się na własnych celach, potrzebach, rozwoju kariery zawodowej i wygodnym życiu (Slany, Szczepaniak-Wiecha 2003; Slany 2008; Szlendak 2011; Żurek 2010). Pokazuje to, że zmianie ulega dawna hierarchia wartości, a także normy społeczne i religijne mające na celu zapewnienie rodzinie jej nierozerwalnego charakteru i dozgonnej odpowiedzialności za nią (Dębski 2008; Dziewięcka-Bokun 2010; Szlendak 2011). U ludzi uwidacznia się indywidualistyczna orientacja na życie i koncentracja na osiąganiu własnych celów, co może przyczyniać się do osłabienia więzi rodzinnych (Dębski 2008; Dziewięcka-Bokun 2010; Szlendak 2011).

Kobiety coraz częściej są postrzegane jako równorzędne mężczyznom, łączy ich więź oparta na partnerskich stosunkach, a nie na tradycyjnym podziale ról czy sztywno obowiązujących normach i zasadach (Bakiera 2006; Kwak 1994; Kotlarska-Michalska 2012; Żurek 2010). Wraz z nadejściem nowych trendów kulturowych stały się bardziej niezależne (Szlendak 2001), a ich rolą nie jest wyłącznie zajmowanie się domem i dbanie o członków rodziny (Kocik 2002). Ze względu na zwiększający się na przestrzeni lat dostęp do edukacji, chcą się kształcić i rozwijać zawodowo (Kocik 2002; Kwak 1994, 2012; Slany 2008), aczkolwiek czasem są zmuszone do podjęcia pracy zarobkowej, by utrzymać na odpowiednim poziomie budżet rodziny. Obie sytuacje mogą również przyczyniać się do ograniczenia ilości posiadanych lub planowanych potomków albo też całkowitej rezygnacji z bycia rodzicem (Szlendak 2001). Zauważa się, także że kobiety coraz rzadziej poczuwają się do obowiązku posiadania dziecka, a decyzję o powiększeniu rodziny opierają głównie na własnych pragnieniach i możliwościach ekonomicznych (Kotlarska-Michalska 2012). Ponadto zdarza się, że kobiety z wyższym wykształceniem całkowicie rezygnują z bycia matką (Kocik 2002). Powyższy trend wyznacza również kultura masowa, która propaguje coraz większy liberalizm w postawach i poglądach (Kowalska 1999), co sprawia, że zmniejsza się wartość tradycji w codziennym życiu. W tym kontekście duże znaczenie ma jednak miejsce zamieszkania, ponieważ ludność z obszarów wiejskich bardziej ukierunkowana jest na pielęgnowanie tradycji i wierność normom społecznym, natomiast osoby zamieszkujące w aglomeracjach częściej decydują się na nowoczesne formy życia (Miczyńska-Kowalska 2008).

$\mathrm{Na}$ podstawie przytoczonych informacji, można zaobserwować, że zmiany zachodzące w społeczeństwach na przestrzeni lat powodują osłabienie znaczenia przypisywanego małżeństwu i wzrost popularności alternatywnych form życia $\mathrm{z}$ drugą osobą. Niniejszy artykuł ma więc na celu określenie znaczących czynników przyczyniających się do zawierania małżeństw lub decydowania się na rozwód, z uwzględnieniem zjawisk takich jak: małżeństwa powtórne, separacje, związki kohabitacyjne oraz życie w pojedynkę, a także opisanie determinantów, które skłaniają osoby żyjące w związkach do ich sformalizowania, rozwiązania lub pozostawania $\mathrm{w}$ relacji nieformalnej.

\section{Decyzje o małżeństwie}

W toku zachodzących zmian społeczno-kulturowych zmniejsza się ilość zawieranych małżeństw na rzecz osób żyjących w związkach kohabitacyjnych lub w pojedynkę (Bakiera 2008; Kubiak, 2008; Slany 2008, Szukalski 2013). Jednakże w porównaniu do okresu między latami 20, a 60 XX wieku zwiększa się wiek, w którym para decyduje się na ślub (Kwak 2005; Miczyńska-Kowalska 2008; Szukalski 2013) oraz na ewentualne posiadanie potomstwa (Slany 2008; Żurek 2010). Może wiązać się to z coraz dłuższym okresem zamieszkiwania młodych dorosłych samotnie (Slany 2008; Żurek 2010) lub z rodzicami z powodu łączącej ich emocjonalnej więzi czy też niewystarczających zasobów finansowych (Beisert 2006; Slany 2008; Żurek 2010). Decyzja o opóźnieniu zawarcia małżeństwa podyktowana jest również chęcią i koniecznością uzyskania niezależności finansowej, odebrania adekwatnego wykształcenia i zdobycia pracy (Falcman, Koperski 2010; Slany 2008; Zaborowska 2012), dzięki której owa swoboda materialna może zostać osiągnięta. Ponadto z przekładaniem czasu formalizacji związku wiąże się obawa przed monotonią, a także poczucie odpowiedzialności i zależności od partnera (Błasiak, Dybowska 2012).

Decyzja o zawarciu małżeństwa podyktowana jest natomiast uczuciem miłości, chęcią zaspokojenia potrzeb bliskości i poczucia bezpieczeństwa, lękiem przed samotnością, a także pragnieniem posiadania potomstwa oraz zrealizowaniem planu wynikającego z biegu życia (Adamski 2002; Bakiera 2008, Błasiak, Dybowska 2012, Doniec 2001; Duch-Krzystoszek 1998; Kwak 1994; Żurek 2010). Kolejnymi powodami, które sprawiają, że partnerzy decydują się na sformalizowanie związku są nie tylko osobowość drugiej osoby i jej wygląd fizyczny (Żurek 2010), ale także tradycja, przekonanie o większej pewności, trwałości i bezpieczeństwie takiej relacji oraz ufność pokładana w instytucję jaką jest małżeństwo (Skopińska 2011). W badaniach Skopińskiej (2011) najważniejszymi powodami, które przemawiały za zawarciem małżeństwa były: dobro potomka, uregulowana pozycja prawna jak również wystarczający czas, który minął na wzajemne zapoznawanie się. Opinia rodziny oraz społeczeństwa, a także sprawy związane z dobrami majątkowymi tylko w niewielkim stopniu były powodami, dla których para mogłaby zdecydować się na ślub (Skopińska 2011). 


\section{Podłoże rozwodów i separacji}

Za główną przyczynę częstszego występowania zjawiska rozwodów uważa się coraz lepsze wykształcenie i coraz większą ilość posiadanych pieniędzy, zaangażowanie w karierę zawodową (Kocik 2002; Szlendak 2011; Udry 1981 za: Rydzewski 2010), a także fakt, że zawarcie związku małżeńskiego nie jest już jedynym i koniecznym wyborem (Adamski 2002: 157). Brak poczucia nierozerwalności związku formalnego może być przyczyną koncentracji głównie na sobie, własnych celach, dążeniach (Dudziak 2012; Kocik 2002; Zaborowska 2012) lub na pracy zawodowej (Przybysz- Zaremba 2008), a nie na potrzebach drugiej osoby, co sprawia, że instytucja rodziny i małżeństwa traci swoja stabilność (Dudziak 2012; Kocik 2002; Zaborowska, 2012). Na zwiększoną możliwość rozwiązania małżeństwa wpływa także: zamieszkiwanie w większych ośrodkach miejskich, lewicowe przekonania polityczne (CBOS, BS/43/2008; Rydzewski 1999 za: Rydzewski 2010), zawarcie związku formalnego w młodym wieku (Spanier, Glick 1981), ciąża kobiety, a także zbyt duża różnica wieku lub poziomu wykształcenia między małżonkami (Kocik 2002). Najrzadziej decyzja o rozwodzie podejmowana jest natomiast na terenach wiejskich i w małych miasteczkach oraz wśród osób z niskim wykształceniem (Kocik 2002; Rydzewski 2010) często z uwagi na większą religijność, tradycjonalność i większe uzależnienie finansowe partnerów od siebie nawzajem (Szukalski 2013).

Do podjęcia decyzji o rozwodzie małżonków często skłania: zdrada partnera, niedopasowanie charakterów, zbyt duża ilość spożywanego alkoholu (Beczkiewicz 2008; Żebrowski 2002), przemoc, kłopoty mieszkaniowe (Kawula 2005) i finansowe, brak umiejętności zarządzania pieniędzmi (Beczkiewicz 2008), brak więzi pomiędzy współmałżonkami (Kwak 2005), nieudane współżycie seksualne (Kawula 2005) lub zamieszkiwanie partnera $w$ innym kraju (Miczyńska-Kowalska 2008; Szukalski 2010, 2011a). Przyczyną rozwodów są także różnice w poglądach i inna hierarchia wartości, w tym tych związanych z posiadaniem potomstwa i kształtowaniem ich rozwoju (Kocik 2002), rywalizacja partnerów na polu zawodowym, brak potrzeby bycia wiernym, odpowiedzialnym (Kawula 2005), nieumiejętność komunikacji, wyrażania emocji i rozwiązywania konfliktów, jak również nadmierna zazdrość partnera, huśtawka nastrojów oraz infantylność przejawiająca się nieprzygotowaniem do życia w małżeństwie (Beczkiewicz 2008; Kawula 2005; Kułaczkowski 2008; Ostrowska, Korwin-Szymanowska 2013). Badania wskazują, że na przestrzeni ostatniego dziesięciolecia, w porównaniu do lat 60 ubiegłego wieku, wzrosło znaczenie braku bezpieczeństwa finansowego, popełnienia przestępstwa i zdrady małżeńskiej jako przyczyn rozwodu. Natomiast niemożność posiadania dzieci przez jednego z partnerów, choroba przewlekła lub zaburzenia psychiczne nie były tak często jak dawniej powodami, które wią- zały się z koniecznością zakończenia związku formalnego (Beisert 2006; CBOS BS/43/2008; CBOS BS/36/2013). Ponadto zarówno w Polsce jak i w Europie, małżeństwa czasami rozpadają się z prozaicznych powodów, które przyczyniły się do pogorszenia relacji i zapoczątkowania sporów między partnerami (Kocik 2002).

Złe przykłady wyniesione z domu rodzinnego czy doświadczenie rozwodu własnych rodziców (Dudziak 2012) również przyczyniają się do niemożności poznania prawidłowych wzorców małżeńskich i rodzinnych (Stankowska 2012). Może to skutkować wyzbyciem się lęku przed kolejnym doświadczeniem rozpadu małżeństwa (Kułaczkowski 2008; Zaborowska 2012), nawet własnego. Poza tym, coraz bardziej powszechny staje się pogląd, iż rozwód daje szansę na znalezienie lepszego partnera, a dzieciom umożliwia bardziej optymalny rozwój w środowisku domowym (Kwak 2014). Takie przekonanie może być dodatkowo wzmacniane przez poglądy rodziny i znajomych wyrażających pozytywną opinię na temat końca małżeństwa, zwłaszcza z uwagi na rozpowszechnienie rozwodów, liberalizację osądów (Szukalski 2013), wzorowanie się na celebrytach i znanych osobistościach, mniejszą religijność bądź odrzucanie wartości propagowanych przez Kościół (Kułaczkowski 2008; Zaborowska 2012). Natomiast małżonkowie w długoletnich związkach często decydują się na rozwód z powodu subiektywnego poczucia zmęczenia lub zniechęcenia obecnym związkiem bądź partnerem i braku zauważalnych u niego długo oczekiwanych zmian (Szukalski 2013). Ryzyko rozejścia się małżonków zwiększa się również, gdy para jest bezdzietna $\mathrm{z}$ powodu braku poczucia wspólnoty (Andersson 1997; Przybysz-Zaremba 2008), a także wraz z wiekiem potomstwa, lub gdy para ma więcej niż czworo dzieci (Andersson 1997), choć na terenach wiejskich może stanowić to czynnik stabilizujący małżeństwo (Szukalski 2013). Dzieje się tak z uwagi na osłabienie więzi między małżonkami wynikających z niemożności podołania obowiązkom rodzicielskim, oraz gdy zakończył się okres zależności żony od męża spowodowany koniecznością zapewnienia jej i potomstwu pomocy fizycznej i materialnej (Heaton 1990 za: Rydzewski 2010). Ponadto wyobrażenie sobie życia bez dotychczasowego małżonka (Lyngstad 2006; Albrecht, Kunz 1980 za: Rydzewski 2010) oraz zaspokojenie pragnienia niezależności i realizacji swoich celów (Albrecht, Kunz, 1980 za: Rydzewski 2010) również wpływają na decyzję o zakończeniu małżeństwa, zamiast jego naprawy. Można spekulować, że odkąd rozwód stanie się dla obecnych małżonków bardziej opłacalny pod jakimkolwiek względem, to na jego rzecz zrezygnują z pozostawania w dotychczasowej, niezbyt satysfakcjonującej dla nich relacji (Lyngstad 2006).

Separacja natomiast to stan, w którym dotychczasowi małżonkowie nadal pozostają w związku formalnym, jednakże od strony prawnej ich sytuacja wygląda prawie jak po rozwodzie, na przykład pod względem rozdzielności majątkowej czy też 
niemożności otrzymania spadku po współmałżonku. Na podjęcie decyzji o separacji najczęściej wpływa wyznawana religia, która nie dopuszcza możliwości rozwodu, nawet mimo niesatysfakcjonującego małżeństwa, przekonanie, że w sądzie separacja $w$ porównaniu do orzeczenia o rozwodzie będzie łatwiejsza do uzyskania, a także nadzieja na ewentualne pogodzenie się z małżonkiem w przyszłości (Szukalski 2013, 2013a). Mimo iż zdarza się, że separacja zostaje zniesiona, a para powraca do wspólnego pożycia, to znacznie częściej decyzja o separacji poprzedza jedynie decyzję o trwałym rozwiązaniu małżeństwa (GUS 2015). Badania pokazują, że przyczyny, które spowodowały podjęcie decyzji o separacji były podobne do tych warunkujących rozwód. Wśród nich dominowały czynniki takie jak: niedopasowanie charakterologiczne, nadużywanie alkoholu, brak wierności, konflikty finansowe, nieodpowiedni stosunek do rodziny (Szukalski 2013, 2013a) oraz choroby przewlekłe (Kawula 2005). Na separację najczęściej decydują się osoby mieszkające w miastach (Szukalski 2013a) z uwagi na ich większy liberalizm w poglądach dotyczących kończenia związków formalnych. Na wsiach korzystano z tej możliwości z powodu uznawania takiej formy rozstania się z obecnym małżonkiem za łagodniejszą i bardziej aprobowaną społecznie, gdyż nie oznaczała ona definitywnego zakończenia związku małżeńskiego (Szukalski 2013).

\section{Małżeństwa powtórne szansą na ponowne szczęście?}

Ponowne zawarcie małżeństwa jest skutkiem rozpadu poprzedniego związku formalnego z powodu rozwodu lub śmierci małżonka (Sherkat 2004). Liczba małżeństw powtórnych, zwłaszcza od czasów powojennych, rośnie najprawdopodobniej z uwagi na zwiększającą się liczbę rozwodów i dużą liczbę osób w starszym wieku, co jest spowodowane wydłużaniem się przeciętnej długości życia (Szukalski 2011). W porównaniu do Polski, w Europie Zachodniej można zaobserwować jeszcze większy wzrost ilości ponownych małżeństw, gdyż rozpada się tam około 40-50\% związków formalnych zawieranych po raz pierwszy (Szukalski 2011). Powody, dla których podejmowana jest decyzja o ponownym małżeństwie mogą być bardzo różne. Można do nich zaliczyć pragnienie zapomnienia o poprzednim niefortunnym związku formalnym, próbę ponownego ułożenia sobie życia, spotkanie osoby którą obdarzy się uczuciem namiętności, a także zaspokojenie potrzeby przynależności oraz niechęć posiadania mało pożądanego statusu społecznego osoby rozwiedzionej. Powtórne małżeństwa zawierane są również z uwagi na obawę przed odosobnieniem i osamotnieniem przejawiającą się $\mathrm{w}$ chęci posiadania kogokolwiek i mieszkaniu z drugą osobą, nieumiejętność podołania codziennym problemom, chęć poprawy warunków rodzinnych, bytowych i rozwojowych lub pragnienie posiadania potomstwa (Witczak $1983 \mathrm{za}$ :
Kurlak 2011; Kurlak 2011). Ponadto pozostawanie w związku małżeńskim w przypadku osób starszych wywiera korzystny wpływ na długość ich życia i stan zdrowia, za sprawą możliwości bycia otoczonym opieką drugiej osoby (Frątczak, Sobieszak 1999 za: Kałuża 2010; Szukalski 2007).

\section{Związki kohabitacyjne jako alternatywa dla małżeństwa}

Wzrost częstości występowania zjawiska kohabitacji czyli decydowania się na wspólne życie bez formalizowania związku, zauważalny był już w latach 70, nie tylko u młodych dorosłych, ale i rozwodników, wdowców czy ludzi żyjących w pojedynkę (Kiernan 1999 za: Slany 2008). Według Slany (2002), dane zebrane na początku XXI wieku pokazują, że w Polsce młodzi dorośli w porównaniu do dorosłych w przedziale wiekowym 30-60+, odwrotnie niż w państwach Europy Zachodniej, stanowili raczej mały odsetek par żyjących w związkach nieformalnych (Kocik 2002). Z nowszych danych wynika jednak, że na kohabitację coraz częściej decydują się ludzie z wykształceniem wyższym lub będący w trakcie jego zdobywania (Slany 2001 za: Slany 2008), czyli najczęściej osoby młode, poniżej 30 roku życia (Szlendak 2011).

Związki kohabitacyjne mogą stanowić etap przejściowy między zawarciem pierwszego bądź kolejnego związku formalnego lub mogą być rozwiązaniem na stałe, jeśli para nie ma ochoty lub nie może zawrzeć związku formalnego (Jabłoński, Ostasz 2001). Może być to spowodowane, na przykład niechęcią przejawianą w stosunku do instytucji małżeństwa (McRae 1999 za: Szlendak 2011; Sikora 2008), lękiem przed zawarciem długoterminowej formalnej relacji (Błasiak, Dybowska 2012) lub problemami pojawiającymi się $\mathrm{w}$ trakcie rozwodu jednego z kohabitantów, co może udaremnić rozwiązanie poprzedniego związku formalnego (Kocik 2002; McRae 1999 za: Szlendak, 2011; Szlendak 2011). Na kohabitację często decydują się także osoby, które doświadczyły rozwodu swoich rodziców i żyły w rodzinie niepełnej (Błasiak, Dybowska 2012) lub były wychowywane przez rodziców, którzy również nie byli małżeństwem (Kamińska-Moczyło 2014). Związki nieformalne mogą być poza tym próbą sprawdzenia koegzystencji z aktualnym partnerem (Kwak 2005; McRae 1999 za: Szlendak 2011; Sikora, 2008; Skopińska 2011) lub krótkotrwałą relacją bez większych zobowiązań, w przypadku niechęci by wiązać się z jednym partnerem na stałe (Kwak 2005; Jabłoński, Ostasz 2001; Ostrowska, Korwin-Szymanowska 2013; Sikora 2008; Skopińska 2011), gdyż taka forma związku pozwala na łatwe wycofanie się z niego w przypadku niesatysfakcjonującej relacji (Ostrowska, Korwin-Szymanowska 2013; Skopińska 2011). Innym powodem może być przejawianie liberalnego światopoglądu w aspekcie zmian stanu cywilnego (Thornton i in. 1992) i niechęć do tradycyjnego podziału ról w rodzinie (Kwak 2005). Koha- 
bitacja wybierana jest także w sytuacjach, gdy partnerzy obawiają się ewentualnego szybkiego rozpadu związku w przypadku jego sformalizowania (Kwak 2005; Jabłoński, Ostasz 2001; Ostrowska, KorwinSzymanowska 2013; Sikora 2008; Skopińska 2011), poszukują nowości w bliskich związkach, żywią obawy przed monotonią (Jabłoński, Ostasz 2001) w małżeństwie oraz gdy pragną większej możliwości samorealizacji czy też braku jakichkolwiek zobowiązań (Kwak 2005; Ostrowska, Korwin-Szymanowska 2013; Sikora 2008; Skopińska 2011). Na związek nieformalny partnerzy mogą decydować się również z powodów ekonomicznych takich jak na przykład niewystarczająca ilość pieniędzy na wspólne mieszkanie, ślub i uroczystość weselną (Kwak 2005; McRae 1999 za: Szlendak 2011).

\section{Single z wyboru lub z konieczności}

Single to nie tylko osoby, które chcą żyć w pojedynkę $\mathrm{z}$ powodu własnych przekonań, ale również takie, które chciałyby w przyszłości stworzyć satysfakcjonującą relację z drugą osobą (Ładyżyński 2009; Zurek 2010). Liczba osób wybierających życie w pojedynkę ciągle rośnie, jednak wzrost tego zjawiska zaczęto obserwować od drugiej połowy XX wieku (Miczyńska-Kowalska 2008; Żurek 2010). Spowodowane jest ono zatraceniem poczucia wspólnoty w kontaktach z ludźmi oraz niesatysfakcjonującymi relacjami z płcią przeciwną (Ładyżyński 2009; Żurek 2010).

Osoby, które nie mają zamiaru wchodzić w żadne relacje (Ładyżyński 2009; Żurek 2010), lub które po doświadczeniu własnego rozwodu czy rozpadu nieformalnej relacji nie mają ochoty na stworzenie nowego związku (Kułaczkowski 2008; Ruszkiewicz 2008; Zaborowska 2012) często z własnej woli postanawiają żyć samotnie. Bywa to spowodowane przekonaniem, że małżeństwo nie jest formą związku pasującą do nowoczesnego świata, która dawałaby gwarancję udanego życia, gdyż zachodzące na przestrzeni lat zmiany społeczno-kulturowe spowodowały, że ceniony status społeczny uzyskuje się nie przez posiadanie małżonka, a poprzez sukcesy osiągnięte przez jednostkę (Żurek 2006). Singlami są także osoby, które mimo chęci nie znalazły partnera, z którym mogłyby zawrzeć związek formalny (Kocik 2002), a także te, które były już kiedyś w związku małżeńskim i chciałyby w przyszłości wejść w kolejną relację. Powodem ich samotnego życia jest niemożność znalezienia adekwatnej osoby, z którą mogłyby stworzyć udaną parę (Ruszkiewicz 2008). W Polsce, podobnie jak w wielu innych krajach zwiększa się również ilość samotnych rodziców. Najczęściej są to samotne matki. Jednakże niektóre kobiety świadomie decydują się na samotne wychowywanie potomstwa, a inne nie mają wyboru, gdyż zostały matkami przypadkowo, nie planując powiększenia rodziny (Racław-Markowska i in. 2001).

\section{Podsumowanie}

Aktualnie obserwowane trendy dotyczące zmian stanu cywilnego, przejawiają się w spadku ilości zawieranych małżeństw, zwiększającej się liczbie rozwodów, związków nieformalnych i popularności życia w pojedynkę zauważalne są praktycznie w każdym europejskim kraju. Wpływ na tę sytuację mają społeczne i ekonomiczne przeobrażenia (Kotowska 1999; Giza-Poleszczuk 2007) popularyzujące model rodziny z małą ilością dzieci lub par całkowicie bezdzietnych. Duże znaczenie ma również zmieniająca się hierarchia norm i wartości, stawiająca na pierwszym miejscu dbanie o własne szczęście i samorealizację, a także satysfakcję płynącą z bycia z drugą osobą, zamiast usilnego starania się by jak najlepiej wypełniać role rodzinne i społeczne związane z płcią (Dziewięcka-Bokun 2010; Szlendak 2011). Ponadto niebagatelne znaczenie odgrywa także kultura masowa zorientowana na propagowanie coraz bardziej liberalnych postaw i poglądów (Kowalska 1999), co znajduje odzwierciedlenie $\mathrm{w}$ przejawianym w coraz mniejszym stopniu oporze związanym $\mathrm{z}$ wyborem życia w pojedynkę, egzystencji w związku nieformalnym, całkowitej rezygnacji z posiadania dzieci czy podjęciem decyzji o zakończeniu małżeństwa. Na podstawie obserwacji zachodzących zmian $\mathrm{z}$ pewną dozą prawdopodobieństwa, można stwierdzić, iż jednostki będą wybierały formy życia w ich subiektywnym odczuciu dla nich najlepsze, a nie tak jak kiedyś, sugerując się tradycją, w obawie o przestrzeganie norm społecznych będą wchodziły w niesatysfakcjonujące związki i pełniły role społeczne, których pełnić nigdy nie chciały.

\section{Literatura:}

1. Adamski F. (2002), Rodzina, Wymiar społeczno-kulturowy. Wydawnictwo Uniwersytetu Jagiellońskiego, Kraków.

2. Allen S.M., Kalish R.A. (1984), Professional Women and Marriage. Journal of Marriage and the Family, 46 (2), s. 375-382.

3. Andersson G. (1997), The Impact of children on divorce risks of Swedish women. European Journal of Population, 13, s. 109-145.

4. Bakiera L. (2006), Rodzina z perspektywy socjologicznej i psychologicznej: ciagłość i zmiana. Obrazy życia rodzinnego z perspektywy interdyscyplinarnej. Roczniki Socjologii Rodziny XVII UAM, s. 101-115.

5. Bakiera L. (2008), Postawy młodych dorosłych wobec małżeństwa. Psychologia Rozwojowa, 13(3), http:// www.ejournals.eu/sj/index.php/PR/article/view/3989, (data dostępu: 10.05.2016). 
6. Beczkiewicz M. (2008), Retrospektywny obraz rozpadu rodziny w oczach dorosłych dzieci, W: W. Muszyński, E. Sikora (red.), Małżeństwo i rodzina w ponowoczesności. Szanse, zagrożenia, patologie. Wydawnictwo Adam Marszałek, Toruń, s. 326-337.

7. Beisert M. (2006), Przemiany współczesnej rodziny polskiej. Rocznik Lubuski, 32, cz. 2, http://www.zbc. uz.zgora.pl/Content/6346/rocz32-2.pdf\#page=17, (data dostępu: 10.05.2016).

8. Błasiak A., Dybowska E. (2012), Ślub kościelny. Dlaczego nie? Pedagogiczno-psychologiczne aspekty pracy nad soba $w$ czasie przygotowania do małżeństwa i w małżeństwie. Teologia i moralność, 12, http://pressto.amu.edu.pl/index.php/tim/article/view/5227, (data dostępu: 10.05.2016).

9. Boguszewski R. (2008), Stosunek Polaków do rozwodów. CBOS, BS/43/2008, http://cbos.pl/SPISKOM. POL/2008/K_043_08.PDF, (data dostępu: 10.05.2016).

10. Boguszewski R. (2013), Polacy o rozwodach. CBOS, BS/36/2013, http://cbos.pl/SPISKOM. POL/2013/K_036_13.PDF, (data dostępu: 10.05.2016).

11. Duch-Krzystoszek D. (1998), Małżeństwo, seks, prokreacja. Analiza socjologiczna. Wydawnictwo IFiS PAN, Warszawa.

12. Dudziak U. (2012), Polacy wobec rozwodów. Przyczyny i skutki rozpadu rodziny oraz wskazania profilaktyczne. Studia Warmińskie 49, https://www.infona.pl/resource/bwmeta1.element.desklight30485221-2bc7-4312-be8d-6e55d4184de3, (data dostępu: 10.05.2016).

13. Dziewięcka-Bokun L. (2010), Rodzina jako autoteliczna wartość polityki społecznej, W: A. Kubów, J. Szczepaniak (red.), Współczesne wyzwania polityki społecznej wobec rodziny. Uniwersytet Ekonomiczny we Wrocławiu, Wrocław, s. 25-30.

14. Dębski M. (2008), Sytuacja bezdomnych kobiet w województwie pomorskim, W: Forum. O bezdomności bez lęku. Pomorskie Forum na Rzecz Wychodzenia z Bezdomności, Gdańsk, https://www.researchgate.net/ profile/Maciej_Debski/publication/262635990_SYTUACJA_BEZDOMNYCH_KOBIET_W_WOJEWODZTWIE_POMORSKIM/links/0deec53848b2778c54000000.pdf, (data dostępu: 10.05.2016).

15. Doniec R. (2001), Rodzina wielkiego miasta. Przemiany społeczno-moralne w świadomości trzech pokoleń. Wydawnictwo Uniwersytetu Jagiellońskiego, Kraków.

16. Falcman D., Koperski Ł. (2010), Bycie singlem jako nowa koncepcja życia i alternatywa wobec małżeństwa, zalety $i$ wady życia $w$ rodzinie i poza rodzina. Roczniki Socjologii Rodziny, XX, s. 73-91.

17. Giza-Poleszczuk A. (2007), Rodzina i system społeczny, W: M. Marody (red.), Wymiary życia społecznego. Polska na przełomie XX i XXI wieku. Wydawnictwo Scholar, Warszawa, s. 290-317.

18. Główny Urząd Statystyczny (2015), Notatka informacyjna. Podstawowe informacje o rozwoju demograficznym Polski do 2014 roku, http://stat.gov.pl/files/gfx/portalinformacyjny/pl/defaultaktualnosci/5468/12/5/1/podstawowe_informacje_o_rozwoju_demograficznym_polski_do_2014.pdf, (data dostępu: 10.05 .2016$)$.

19. Lyngstad T. H. (2006), Does community context have important bearings on the divorce rate? A fixed-effects study of twenty Norwegian first-marriage cohorts. Vienna Institute of Demography Working Papers, 6, https://www.econstor.eu/bitstream/10419/96982/1/52076126X.pdf, data dostępu: 10.05.2016).

20. Ładyżyński A. (2009), Małżeństwo? Nie dziękuję! Rzecz o przyczynach niezawierania zwiq̨zków, W: A. Ładyżyński (red.), Rodzina we współczesności. Oficyna Wydawnicza ATUT, Wrocław, s. 259-269.

21. Łukasiewicz A.M. (2011), Współczesne formy kohabitacji w Polsce - ujęcie teoretyczne, W: H. Liberska i A. Malina (red.), Wybrane problemy współczesnych małżeństw i rodzin. Difin S.A., Warszawa, s. 57-68.

22. Jabłoński D., Ostasz L. (2001), Zarys wiedzy o rodzinie, małżeństwie, kohabitacji i konkubinacie. Perspektywa antropologii kulturowej i ogólnej. Wydawnictwo Adiaphora, Olsztyn.

23. Kałuża D. (2010), Nowożeńcy w „późnym wieku” w Polsce, W: D. Kałuża, P. Szukalski (red.), Jakość życia seniorów w XXI wieku z perspektywy polityki społecznej. Uniwersytet Łódzki, Łódź, s. 289-304.

24. Kamińska-Moczyło K. (2013), Polityka rodzinna w hasłach programowych relewantnych partii politycznych Republiki Federalnej Niemiec, W: Umiędzynarodowienie polskiej polityki społecznej - aspekty globalne i europejskie. Polskie Towarzystwo Polityki Społecznej, Uniwersytet Gdański, Gdańsk, https://depot.ceon. pl/bitstream/handle/123456789/7535/Zmiany\%20w\%20modelach\%20rodziny.pdf?sequence=1\&isAllowed=y, (data dostępu: 10.05.2016).

25. Kawula S. (2005), Kształty rodziny współczesnej. Szkice familiologiczne. Wydawnictwo Adam Marszałek, Toruń.

26. Kocik L. (2002), Wzory małżeństwa i rodziny: od tradycyjnej jednorodności do współczesnych skrajności. Krakowskie Towarzystwo Edukacyjne, Kraków.

27. Kotlarska-Michalska A. (2001), Przemiany rodzinnych ról kobiecych w okresie transformacji ustrojowej, W: Z. Tyszka (red.). Współczesne rodziny polskie - ich stan i kierunek przemian. Wydawnictwo Naukowe UAM, Poznań, s. 93-103.

28. Kotlarska-Michalska A. (2012), Główne kierunki przemian w kobiecych rolach małżeńskich i macierzyńskich, W: A. Kwak, M. Bieńko (red.), Wielość spojrzeń na małżeństwo i rodzinę. Wydawnictwa Uniwersytetu Warszawskiego, Warszawa, s. 87-115. 
29. Kotowska I.E. (1999), Drugie przejście demograficzne i jego uwarunkowania, W: I. Kotowska (red.), Przemiany demograficzne $w$ Polsce $w$ latach 90-tych $w$ świetle drugiego przejścia demograficznego. Oficyna Wydawnicza Szkoły Głównej Handlowej, Warszawa, s. 11-33.

30. Kowalska I. (1999), Zmiany procesu tworzenia i rozpadu małżeństw w Polsce, W: I. Kotowska (red.), Przemiany demograficzne $w$ Polsce $w$ latach 90-tych $w$ świetle drugiego przejścia demograficznego. Oficyna Wydawnicza Szkoły Głównej Handlowej, Warszawa, s. 99-124.

31. Kubiak M. (2008), Demograficzne uwarunkowania polityki rodzinnej państwa, W: W. Muszyński, E. Sikora (red.), Małżeństwo i rodzina w ponowoczesności. Szanse, zagrożenia, patologie. Wydawnictwo Adam Marszałek, Toruń, s. 17-31.

32. Kułaczkowski J. (2008), Ocena moralna rozwodów w społeczeństwie polskim, a duszpasterstwo rodzin. Teologia i człowiek, 12, http://www.teologiaiczlowiek.umk.pl/pliki/ticz_12_08_ks_jerzy_kulaczkowski. pdf, (data dosteppu: 10.05.2016).

33. Kurlak I. (2011), Blaski i cienie powtórnego zamążpójścia. Andragogiczno- feministyczne aspekty rekonstrukcji małżeństwa. Forum Pedagogiczne UKSW, 1, http://yadda.icm.edu.pl/yadda/element/bwmeta1. element.desklight-6b189b65-2df9-4e3a-8122-57f93c884004, (data dostępu: 10.05.2016).

34. Kwak A. (1994), Rodzina i jej przemiany. ISNS UW, Warszawa.

35. Kwak A. (2005), Rodzina w dobie przemian. Małżeństwo i kohabitacja. Wydawnictwo Akademickie Żak, Warszawa.

36. Kwak A. (2012), Od i do małżeństwa i rodziny: „czas” rodziny - „czas jednostki”, W: A. Kwak, M. Bieńko (red.), Wielość spojrzeń na małżeństwo i rodzinę. Wydawnictwa Uniwersytetu Warszawskiego, Warszawa, s. 39-60.

37. Kwak A. (2014), Współczesny świat zmian - alternatywy dla małżeństwa. Acta Universitatis Lodziensis, Folia Sociologica, 51, http://yadda.icm.edu.pl/yadda/element/bwmeta1.element.hdl_11089_8695,(data dostępu: 10.05.2016).

38. Miczyńska-Kowalska M. (2008), Konsumpcyjny charakter rodziny w społeczeństwie ponowoczesnym, W: W. Muszyński, E. Sikora (red.), Małżeństwo i rodzina w ponowoczesności. Szanse, zagrożenia, patologie. Wydawnictwo Adam Marszałek, Toruń, s. 133-141.

39. Ostrowska K., Korwin-Szymanowska A. (2013), Znaczenie kształtowania wartości w rodzinie. Referat wygłoszony na: Międzynarodowy Kongres o znaczeniu małżeństwa i rodziny w życiu osoby, społeczeństwa, narodu i świata „Przyszłość ludzkości idzie przez rodzinę”, Warszawa, Polska, http://www.stowarzyszeniefidesetratio.pl/Presentations0/WARTOSCI.pdf, (data dostępu: 10.05.2016)

40. Poleszczuk J. (2002), Rodzina, małżeństwo i prokreacja: racjonalizacja strategii reprodukcyjnych, W: A Jasińska-Kania, M. Marody (red.), Polacy wśród Europejczyków. Wartości społeczeństwa polskiego na tle innych krajów europejskich. Wydawnictwo Scholar, Warszawa, s. 257-279.

41. Przybysz-Zaremba M. (2008), Patologie rodziny współczesnej, W: W. Muszyński, E. Sikora (red.), Małżeństwo i rodzina w ponowoczesności. Szanse, zagrożenia, patologie. Wydawnictwo Adam Marszałek, Toruń, s. 297-305.

42. Racław-Markowska M., Środoń M., Rymsza M. (2001), Portrety samotnego macierzyństwa, W: M. Rymsza (red.), Samotne macierzyństwo i polityka społeczna. Instytut Spraw Publicznych, Warszawa, s. 97-122.

43. Ruszkiewicz D. (2008), Życie w pojedynkę - ucieczka od rodziny czy znak naszych czasów? Wydawnictwo WSHE, Łódź.

44. Rydzewski P. (2010), Socjologiczne analizy rozwodów. Aspekty teoretyczne, empiryczne i metodologiczne. Wydawnictwo WSPA, Lublin.

45. Sherkat D.E. (2004), Religious intermarriage in the United States: trends, patterns, and predictors. Social Science Research, 33, s. 606-625.

46. Sikora E. (2008), Społeczne oczekiwania wobec związku i partnera życiowego -kierunki zmian, W: W. Muszyński, E. Sikora (red.), Miłość, wierność i uczciwość na rozstajach współczesności. Wydawnictwo Adam Marszałek, Toruń, s. 311-323.

47. Slany K. (2008), Alternatywne formy życia małżeńsko-rodzinnego w ponowoczesnym świecie. Zakład Wydawniczy Nomos, Kraków.

48. Slany K., Kluzowa K. (2005), Aksjologiczne aspekty polityki rodzinnej, W: R. Horodeński, E. Ozorowski (red.), Rodzina, etyka, ekonomia. Wydawnictwo WSE, Białystok, s. 131-147.

49. Slany K., Szczepaniak-Wiecha I. (2003), Bezdzietność jako nowy fenomen w nowoczesnym świecie. Małżeństwo i Rodzina, 1, s. 23-28.

50. Skopińska S. (2011), Opinie młodych dorosłych na temat zwiq̨zków nieformalnych, W: H. Liberska i A. Malina (red.), Wybrane problemy współczesnych małżeństw i rodzin. Difin S.A., Warszawa, s. 87-96.

51. Spanier G.B., Glick P.C. (1981), Martial instability in the United States: Some correlates and recent changes. Family Relations, s. 329-338.

52. Stankowska M. (2012), Długoterminowe konsekwencje rozwodu. Problemy dorosłych dzieci z rodzin rozwiedzionych, W: A. Kwak, M. Bieńko (red.), Wielość spojrzeń na małżeństwo i rodzinę. Wydawnictwa Uniwersytetu Warszawskiego, Warszawa, s. 147-176. 
53. Szlendak T. (2011), Socjologia rodziny; Ewolucja, historia, zróżnicowanie. Wydawnictwo Naukowe PWN, Warszawa.

54. Szukalski P. (2007), Zróżnicowanie poziomu umieralności a stan cywilny. Wiadomości Statystyczne, 5, s. 33-44.

55. Szukalski P. (2010), Dzieci po rozwodzie rodziców w Polsce $w$ latach 1980-2007. Polityka społeczna, 4 , http://dspace.uni.lodz.pl/xmlui/bitstream/handle/11089/3461/PS\%202010-4.pdf?sequence=1\&isAllowed=y, (data dostępu: 10.05.2016).

56. Szukalski P. (2011), Małżeństwa powtórne. Demografia i Gerontologia Społeczna -Biuletyn Informacyjny, 12, http://dspace.uni.lodz.pl/xmlui/bitstream/handle/11089/3508/2011-12\%20Ma\%C5\%82\%C5\%BCe\%C5\%84stwa\%20powt\%C3\%B3rne.pdf?sequence=1\&isAllowed=y, (data dostępu: 10.05.2016).

57. Szukalski P. (2011a), Rozwody we współczesnej Polsce. Demografia i Gerontologia Społeczna - Biuletyn Informacyjny, 10, http://dspace.uni.lodz.pl/xmlui/bitstream/handle/11089/3562/2011-10-Rozwody\%20w\%20Polsce.pdf?sequence=1\&isAllowed=y,(data dostępu: 10.05.2016).

58. Szukalski P. (2013), Małżeństwo. Poczq̨tek i koniec. Wydawnictwo Uniwersytetu Łódzkiego, Łódź.

59. Szukalski P. (2013a), Separacje w Polsce w latach 2000-2012. Demografia i Gerontologia Społeczna - Biuletyn Informacyjny, 7, http://dspace.uni.lodz.pl/xmlui/bitstream/handle/11089/3559/2013-07\%20 Separacje.pdf?sequence=1\&isAllowed=y, (data dostępu: 10.05.2016).

60. Thornton A., Axinn W.G., Hill D.H. (1992), Reciprocal effects of religiosity, cohabitation, and marriage. American Journal of Sociology, 98, s. 628-651.

61. Zaborowska A. (2012), Rodzina jako wartość. Konsekwencje przemian wartości małżeńskich i rodzinnych. https://depot.ceon.pl/handle/123456789/6085, (data dostępu: 10.05.2016).

62. Żurek A. (2006), Orientacja na małżeństwo młodych singli. Roczniki Socjologii Rodziny: Obrazy życia rodzinnego z perspektywy interdyscyplinarnej, XVII, https://repozytorium.amu.edu.pl/bitstream/10593/4965/3/03_Aldona_Zurek_Orientacja_na_malzenstwo_mlodych_singli_27-46.pdf, (data dostępu: 10.05.2016).

63. Żurek A. (2010), Atrakcyjność instytucji małżeństwa we współczesnych społeczeństwach. Zalety i wady życia $w$ rodzinie i poza rodzinq. Roczniki Socjologii Rodziny, XX, https://repozytorium.amu.edu.pl/bitstream/10593/4474/1/06_Aldona_Zurek_Atrakcyjnosc\%20instytucji\%20malzenstwa\%20we\%20wspolczesnych_93-108.pdf, (data dostępu: 10.05.2016).

64. Żebrowski J. (2002), Współczesne przeobrażenia w funkcjonowaniu rodziny polskiej, W: J. Żebrowski (red.), Rodzina polska na przełomie wieków. Uniwersytet Gdański, Gdańsk, s. 15-25. 